\title{
Inheritance of Low Immunoreactive Human Plasma
}

\section{Dopamine- $\beta$-Hydroxylase}

\author{
RADIOIMMUNOASSAY STUDIES
}

\begin{abstract}
Joel Dunnette and Richard Weinshilboum, Clinical Pharmacology Unit, Departments of Pharmacology and Internal Medicine, Mayo Foundation, Rochester, Minnesota 55901
\end{abstract}

A B S T R A C T Inheritance plays an important role in the determination of human plasma dopamine- $\beta$ hydroxylase (DBH) enzymatic activity. It has been demonstrated that an allele $(d)$ for very low enzymatic plasma $\mathrm{DBH}$ is inherited as an autosomal recessive trait. A radioimmunoassay for human DBH was developed to test the hypothesis that the presence of this allele results in a decrease in plasma DBH protein levels. The mean immunoreactive DBH (IDBH) in blood from a randomly selected population of adolescents was $824 \pm 38 \mathrm{ng} / \mathrm{ml}$ (mean $\pm \mathrm{SEM}, n=134)$. The correlation coefficient of enzymatic DBH with IDBH for this group of 134 adolescents was $0.84(P<0.001)$. Of these subjects, $3.7 \%$ had values of $<100 \mathrm{ng} / \mathrm{ml}$ and appeared to compose a separate subgroup analogous to the $3-4 \%$ of the population that is homozygous for the allele for low enzymatic activity. There was a significant siblingsibling correlation of IDBH values in the 14 sibling pairs included among the 134 subjects studied $(r=0.60$, $P<0.025)$. IDBH was also measured in blood from 56 subjects homozygous ( $d d$ ) for the allele for low enzymatic DBH (enzymatic activity $<50 \mathrm{U} / \mathrm{ml}$ ) and in blood of 80 first-degree relatives of homozygous probands. All but two $d d$ subjects had IDBH levels of $<100$ $\mathrm{ng} / \mathrm{ml}$. Results of family studies were compatible with the autosomal recessive inheritance of an allele for IDBH levels of less than $100 \mathrm{ng} / \mathrm{ml}$ which segregates with the allele for very low enzymatic activity. Average IDBH in blood of 37 obligate heterozygotes as determined by family studies $(D d)$ was $599 \pm 53 \mathrm{ng} / \mathrm{ml}$ (mean \pm SEM), significantly lower than the IDBH values found in a randomly selected population $(P<0.005)$. These results are compatible with the conclusion that

Dr. Weinshilboum is an Established Investigator of the American Heart Association.

Received for publication 5 May 1977 and in revised form 1 July 1977. the presence of the allele for low plasma enzymatic DBH results in a decrease in the quantity of $\mathrm{DBH}$ protein in human plasma.

\section{INTRODUCTION}

Dopamine- $\beta$-hydroxylase (DBH, E.C. 1.14 .17 .1$)^{1}$ catalyzes the conversion of dopamine to norepinephrine (1). DBH is localized to catecholamine-containing vesicles in the adrenal medulla and sympathetic nerves $(2,3)$, is released with catecholamines in response to stimulation (4-8), and is found circulating in blood (9). It has been suggested that plasma $\mathrm{DBH}$ activity might be a useful measure of sympathetic nervous system function in man and experimental animals $(9,10)$, and a variety of clinical studies have been performed in which plasma DBH activity has been measured. However, the interpretation of the results of these studies is difficult because there is a large intersubject variation in human plasma DBH activity that is determined in large part by genetic factors (11). The results of population and family studies are compatible with the existence of an allele $(d)$ for very low plasma enzymatic $\mathrm{DBH}$ activity $(<50 \mathrm{U} / \mathrm{ml})$, that is inherited in an autosomal recessive manner (12). The gene frequency of $d$ is approximately 0.2 , and about one-third of a randomly selected population is heterozygous for this trait (12).

Inherited variations in enzymatic plasma DBH activity might be due either to differences in the quantity of enzyme molecules in blood or to alterations of the enzyme molecule that affect its catalytic ability. To test these hypotheses, an immunoprecipitation technique was used in an earlier study in an attempt

\footnotetext{
${ }^{1}$ Abbreviations used in this paper: DBH, dopamine- $\beta$ hydroxylase; IDBH, immunoreactive dopamine- $\beta$-hydroxylase.
} 
to quantitate immunoreactive DBH in blood samples from randomly selected populations and in blood from subjects with known genotypes for the allele for low plasma DBH enzyme activity. A positive correlation between immunoreactive and enzymatic plasma DBH levels in blood from randomly selected subjects was found with this immunoprecipitation technique (13) and with radioimmunoassay studies by other investigators (14-16). However, it is not possible to use immunoprecipitation to directly quantitate $\mathrm{DBH}$ protein levels in subjects with very low enzyme activity, and no studies of subjects with known genotype for the allele for very low plasma DBH activity have been carried out by radioimmunoassay. Such studies must be performed to test directly the hypothesis that the presence of the allele $d$ results in a decrease in IDBH, to determine whether there is immunoreactive $\mathrm{DBH}$ protein (IDBH) in blood of subjects who are homozygous for the allele $(d d)$, and to determine whether measurement of IDBH might make it possible to identify heterozygotes for this allele $(D d)$, something that cannot be done with measurements of enzymatic activity alone.

\section{METHODS}

Enzymatic dopamine- $\beta$-hydroxylase assay procedure. Enzymatic DBH activity was determined by the method of Molinoff et al. (17) as modified to measure plasma enzyme activity $(9,12)$. Both $\beta$-phenylethylamine and tyramine were used as substrates for DBH. $\beta$-Phenylethanolamine and octopamine, respectively, were used as internal standards for the phenylethanolamine-N-methyltransferase catalyzed portion of the reaction. 1 unit of enzyme activity represented the production of $1 \mathrm{nmol}$ of $\beta$-phenylethanolamine per hour incubated at $37^{\circ} \mathrm{C}$. In the experiments in which tyramine was used as a substrate, activity was expressed as nanomoles of octopamine formed per hour.

Protein assay. Protein concentrations were determined with fluorescamine (18) with bovine serum albumin as a standard.

Purification of human pheochromocytoma dopamine- $\beta$ hydroxylase. DBH was purified from two fresh human pheochromocytomas. Chromaffin granules were prepared from fresh tissue (19) and were lysed by freezing and thawing in $0.1 \%$ Triton X-100 (Rohm \& Haas Co., Philadelphia, Pa.). The lysate was centrifuged at $100,000 \mathrm{~g}$ for $60 \mathrm{~min}$, and the supernate was passed over a Bio-Gel A $1.5 \mathrm{M}$ column (BioRad Laboratories, Richmond, Calif.). The fractions with peak activity were pooled and concentrated. Part of this preparation was used as antigen, and part was further purified by chromatography on a concanavallin A-Sepharose 4B column (Pharmacia Fine Chemicals, Inc., Piscataway, N. J.) as previously described $(20,21)$. This preparation migrated as a single band on disc-gel electrophoresis.

Preparation of antibodies. Two rabbits were immunized by subcutaneous injection on the back with $1.0 \mathrm{mg}$ of the partially purified human pheochromocytoma DBH in an equal volume of Freund's adjuvant. The injections were repeated a month later with antigen plus incomplete Freund's adjuvant. Antisera $\mathbf{N}$ and $\mathrm{O}$ were obtained from separate rabbits 1 wk after the second immunization.

Antiserum I was prepared against human adrenal DBH purified as previously described (13). The antibody was prepared with the same technique as were antibodies against pheochromocytoma DBH.

Burro antisera to rabbit gamma globulin was prepared as previously described (13).

Radio-iodination of DBH. Purified human pheochromocytoma DBH was iodinated by the method of Bolton and Hunter (22). The ${ }^{125}$ I-labeled 3(4-hydroxyphenyl) propionic acid N-hydroxysuccinimide ester was obtained from New England Nuclear, Boston, Mass. (sp act $500 \mathrm{Ci} / \mathrm{mmol}$ ). The benzene in which approximately $1 \mathrm{mCi}$ of the reagent was dissolved was evaporated under vacuum. $10 \mu \mathrm{l}$ of $0.2 \mathrm{M}$ sodium borate, $\mathrm{pH} 8.5$, and $10 \mu \mathrm{l}(4.3 \mu \mathrm{g})$ of purified pheochromocytoma DBH were added to the reagent in rapid succession. The reaction mixture was repeatedly stirred on ice for $30 \mathrm{~min}$, and the reaction was stopped by addition of $200 \mu \mathrm{l}$ of $0.2 \mathrm{M}$ glycine in $0.1 \mathrm{M}$ borate, $\mathrm{pH} 8.5$. After $5 \mathrm{~min}$ of mixing, radiolabeled DBH was separated from the non-proteinbound ${ }^{125} \mathrm{I}$ by gel filtration on a Bio-Gel A $0.5 \mathrm{M}$ column (1.2 $\times 14 \mathrm{~cm}$ ) which had been equilibrated with and was eluted with $0.2 \%$ gelatin in $50 \mathrm{mM}$ potassium phosphate, $\mathrm{pH} 6.5$.

Measurement of $\mathrm{DBH}$ by radioimmunoassay. Immunoreactive DBH was determined with a double antibody radioimmunoassay technique similar to that described by Gleich et al. (23). All reagents were diluted with $1 \%$ bovine serum albumin in $50 \mathrm{mM}$ potassium phosphate, pH 7.4, subsequently referred to as "buffer."

Reagents were added to disposable $12 \times 75 \mathrm{~mm}$ polycarbonate tubes in the following order: (a) DBH standard or the sample to be assayed plus buffer to bring the volume to $0.5 \mathrm{ml} ;(b)$ rabbit anti-DBH $(100 \mu \mathrm{l})$ diluted so as to result in approximately $50 \%$ binding of the labeled DBH; and $(c)$ $100 \mu \mathrm{l}$ of ${ }^{125} \mathrm{I}$-labeled DBH $(0.25 \mathrm{ng})$. After incubation at room temperature for 19-22 $\mathrm{h}$, the following reagents were added to the reaction tubes: $(a) 100 \mu l$ of normal rabbit serum diluted 1:20 (vol/vol) with $50 \mathrm{mM}$ potassium phosphate buffer, pH 7.4, and (b) $100 \mu \mathrm{l}$ of burro antiserum to rabbit gamma globulin. The burro antiserum was added in moderate excess as determined by preliminary quantitative precipitin analysis. After an additional $4 \mathrm{~h}$ of incubation, the tubes were centrifuged at $2,500 \mathrm{~g}$ for $10 \mathrm{~min}$. The supernatant fluid was decanted and the tubes were allowed to drain for $5 \mathrm{~min}$. The radioactivity that remained in the tubes was measured in a Searle 1285 gamma scintillation counter (Searle Analytic Inc., Des Plaines, Ill.). Each tube was prepared in duplicate. A standard curve which included from 0.156 to $40 \mathrm{ng}$ of $\mathrm{DBH}$ and "controls" containing no unlabeled DBH were performed as part of each day's assay. The amount of $\left[{ }^{125} \mathrm{I}\right] \mathrm{DBH}$ precipitated in the presence of unknown samples was determined. The concentration of DBH in the unknown samples was either read directly from the standard curve or was calculated from a semilogarithmic transformation of the standard curve. Tubes that contained ${ }^{\left[{ }^{125} I\right]}$ DBH were tested as a part of each assay in the absence of anti-DBH to determine the number of counts nonspecifically "trapped" in the precipitate. These values ranged from 7.4 to $25.0 \%$ of the "control" values, or $2.1-5.1 \%$ of the total counts added. Antiserum $\mathrm{N}$ was used in all assays unless otherwise noted.

Human plasma samples. Blood samples were obtained from 134 consecutive randomly selected subjects aged 16-18 yr. Blood was withdrawn by venipuncture into heparinized vacuum tubes at school in the morning after an overnight fast. The population studied was so selected that it included only subjects who themselves and whose parents had given written consent. All of these subjects were white (13).

Plasma samples from individuals who were homozygous for the allele for very low plasma DBH activity (enzymatic activity $<50 \mathrm{U} / \mathrm{ml}$ ) and members of their immediate families 
had been obtained in the course of previous studies of the inheritance of plasma DBH enzymatic activity. The manner in which these samples were obtained has been described in detail elsewhere (12).

\section{RESULTS}

Antisera to DBH. Each of the three antisera used was tested by immunodiffusion. All showed a precipitin arc versus pure DBH and versus the crude pheochromocytoma vesicle lysate. After immunoelectrophoresis the precipitin arc was present at a distance from the origin identical with the distance that DBH enzymatic activity migrated. When antiserum was used to immunoprecipitate pure pheochromocytoma DBH, serial increments of DBH enzymatic activity were removed after incubation with increasing quantities of antiserum and $100 \%$ of the DBH enzymatic activity was removed by appropriate concentrations of antiserum. For example, $100 \mu \mathrm{l}$ of a 1:4,000 dilution of antiserum $\mathrm{N}$ entirely titrated the DBH enzymatic activity of $6.7 \mathrm{ng}$ of the pure enzyme preparation.

Characteristics of radiolabeled $D B H$. The radiolabeled DBH retained approximately $65 \%$ of its enzymatic activity. When the chloramine-T labeling method (24) was used in a pilot experiment, no enzymatic activity was retained. The specific activity of the ${ }^{125} \mathrm{I}$ labeled DBH preparation was about $34 \mathrm{mCi} / \mathrm{mg}$.

Characteristics of radioimmunoassay. A typical standard curve for a radioimmunoassay of DBH is shown in Fig. 1. The addition of $1 \mathrm{ng}$ of nonradioactive DBH produced a significant decrease in the binding of ${ }^{125}$ I-labeled DBH. To help ensure that the apparent DBH measured in plasma was antigenically similar to

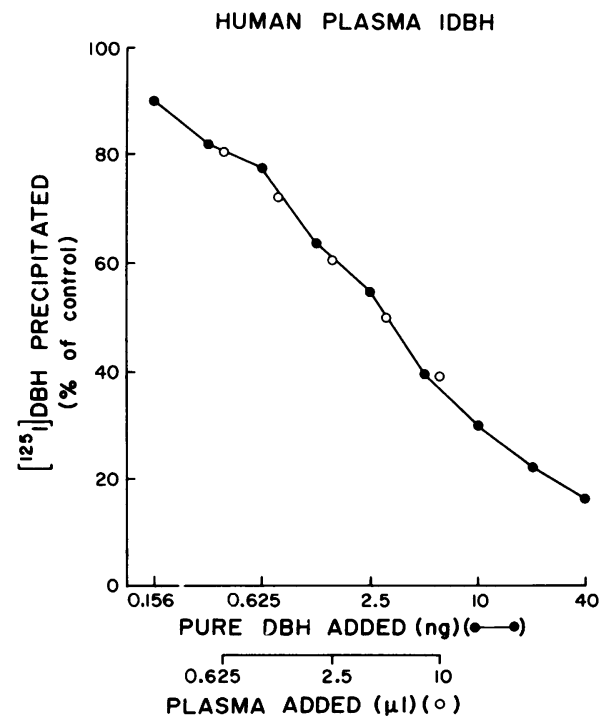

Figure 1 Competitive displacement of ${ }^{125}$ I-labeled DBH by unlabeled pheochromocytoma DBH (O) or by DBH from different dilutions of a single human plasma sample $(O)$.

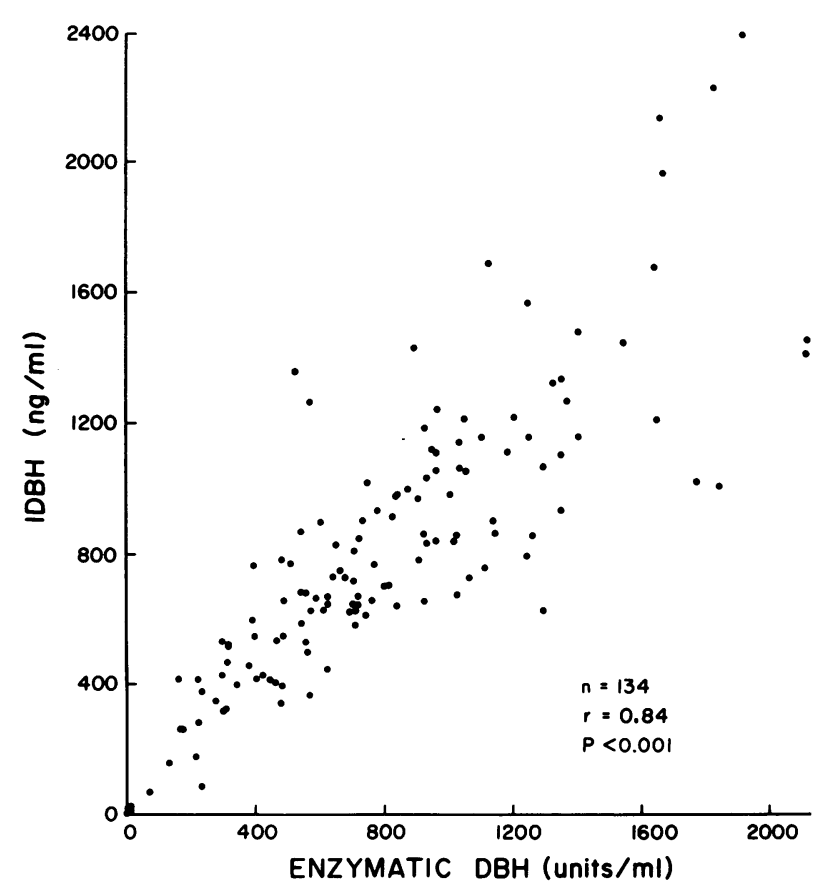

FIGURE 2 Comparison of enzymatic DBH activity with immunoreactive $\mathrm{DBH}$ in 134 plasma samples from a randomly selected population.

the DBH used as a standard, the ability of four separate samples of plasma with different levels of enzymatic activity to inhibit binding were studied. The inhibition curves produced by purified pheochromocytoma DBH and by serial dilutions of the plasma samples were superimposable. The data from the dilution of a single plasma sample are shown in Fig. 1 superimposed on the standard curve obtained for pure DBH. These results suggest that the antigenic characteristics of DBH in plasma do not differ significantly from those of the purified human pheochromocytoma DBH.

Radioimmunoassay of $D B H$ in randomly selected samples. IDBH was measured in samples of plasma obtained from 134 consecutive randomly selected subjects aged 16-18 yr. There was an excellent correlation between enzymatic DBH activity and IDBH levels in blood samples from this population $(r=0.84$, Fig. 2). This finding confirms the results of previous immunoprecipitation and radioimmunoassay studies (13-16). It is significant that the shape of the frequency distribution histogram for IDBH values (Fig. 3, top) is very similar to that previously described for plasma DBH enzymatic activity (12). Of particular interest is the apparent subgroup of subjects with very low levels of IDBH $(<100 \mathrm{ng} / \mathrm{ml})$. The frequency distribution for enzymatic DBH also includes such a subgroup. These subjects $(<50 \mathrm{U} / \mathrm{ml})$ are homozygous $(d d)$ for the allele for very low enzymatic DBH activity which is inherited in an autosomal recessive manner. In both cases the 


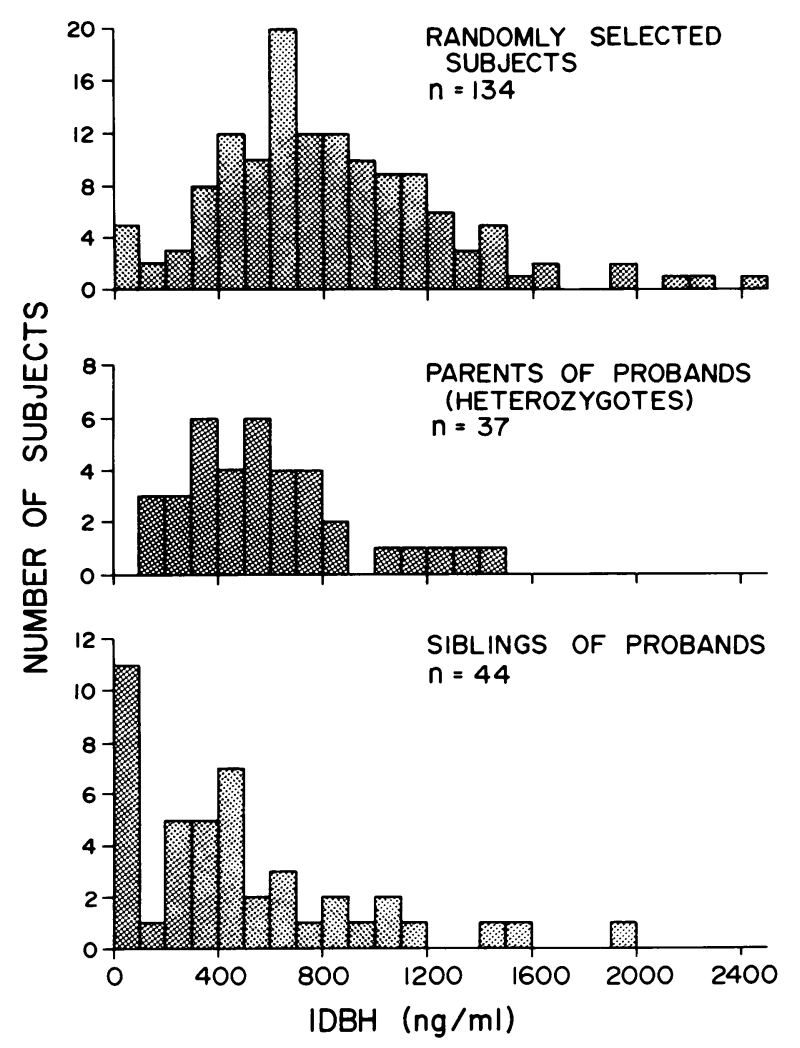

FIGURE 3 Frequency distribution of human plasma immunoreactive DBH. Top, randomly selected subjects. Middle, parents of probands for low IDBH who themselves had IDBH $>100 \mathrm{ng} / \mathrm{ml}$. Bottom, siblings of probands (IDBH $<100 \mathrm{ng} / \mathrm{ml}$ ). Only data from the 15 families in which both parents had IDBH of greater than $100 \mathrm{ng} / \mathrm{ml}$ are included.

subgroups include $3-4 \%$ of a randomly selected population. The gene frequency for the allele for very low enzymatic activity is approximately 0.2 (12). Therefore, approximately $32 \%$ of a randomly selected population is presumed to be heterozygous for the allele. Although enzymatic DBH activity in blood from obligate heterozygotes defined by family studies is significantly lower than that found in blood from a randomly selected population, it is not possible to assign a genotype to an individual subject with a DBH activity of $>50 \mathrm{U} / \mathrm{ml}$ because of overlap in the enzymatic activities in blood from $D d$ and $D D$ subjects. It is significant that although the distribution of IDBH values, like that of enzymatic activity, appears to include a subgroup with very low values, the distribution exclusive of the low IDBH subgroup is not clearly bimodal.

Radioimmunoassay of DBH with additional antisera. In studies of other circulating proteins (e.g., parathyroid hormone), it has been found that different antibody preparations can have different specificities for various antigenic sites on the protein $(25,26)$. Therefore, IDBH was measured in the samples from the same randomly selected population described above with two additional antibody preparations. Antiserum $\mathrm{O}$ (antihuman pheochromocytoma) was used to measure IDBH in the first 20 consecutive samples of the 134 tested with antiserum $\mathrm{N}$. There was an excellent correlation of the results of the two assay procedures $(r=0.93)$. When antiserum I (antihuman adrenal DBH) was used to measure IDBH in the first 42 consecutive samples of the 134 tested with antibody $\mathrm{N}$, a highly significant correlation was also found $(r=0.89)$.

Sibling-sibling correlation of IDBH. Plasma DBH enzymatic activity demonstrates a significant siblingsibling correlation with a correlation coefficient of about 0.5 (11). Included among the 134 randomly selected adolescent subjects for whom IDBH values were determined were 14 sets of sibling pairs. The siblingsibling correlation coefficient was 0.60 , significantly different from zero $(P<0.025)$.

Family studies of IDBH. The significant siblingsibling correlation of IDBH and the significant correlation of IDBH with plasma DBH enzymatic activity raised the possibility that inheritance might play a role in the determination of IDBH values. It was important to determine whether IDBH values in families conform to any of the expected patterns of monogenic inheritance and, if a single gene of large effect influences IDBH values, whether this gene appears to segregate with the allele for very low plasma enzymatic DBH. Therefore, IDBH was measured in blood of subjects with very low enzymatic activity $(<50 \mathrm{U} / \mathrm{ml})$ who had been discovered in the course of a previous study of enzymatic DBH in over 600 blood samples from children aged 6-12 yr (12). Subjects with enzymatic activity of less than $50 \mathrm{U} / \mathrm{ml}$ were considered to be homozygotes for the allele for very low enzymatic activity $(d d)$. In addition, IDBH was measured in blood samples obtained from first-degree relatives of these subjects (probands) in 22 separate families. Of the 56 subjects in these 22 families who had very low enzymatic DBH levels $(<50 \mathrm{U} / \mathrm{ml}), 54$, or $96.4 \%$, had very low IDBH levels $(<100 \mathrm{ng} / \mathrm{ml})$. Among the 80 first-degree relatives of probands who had plasma enzymatic DBH levels greater than $50 \mathrm{U} / \mathrm{ml}, 79$, or $98.8 \%$, had IDBH levels greater than $100 \mathrm{ng} / \mathrm{ml}$. Thus, almost all of the subjects fell into the same classification groups when DBH was measured by either an immunologic or an enzymatic method. The three individuals whose classification changed in one direction or the other were borderline with respect to either the enzymatic activity or the quantity of IDBH. One of the probands for low enzymatic activity had $165 \mathrm{ng} / \mathrm{ml}$ of IDBH. On reassay, the enzymatic activity in the blood of this subject was still low $(<50 \mathrm{U} / \mathrm{ml})$ and IDBH was $170 \mathrm{ng} / \mathrm{ml}$. The possible implications of this observation are discussed in detail below. Because this proband changed classification, the family of this particular proband was not used in 
any of the calculations that follow. Pedigrees for each of the remaining 21 families are shown in Fig. $4 .^{2}$

Although it would seem to follow from the close correlation of relative IDBH and enzymatic DBH values that low IDBH is, like very low enzymatic activity, inherited in an autosomal recessive fashion, the fact

${ }^{2}$ See National Auxiliary Publications Service (NAPS) document No. 03066 for a list of the enzymatic and IDBH values of each individual represented in Fig. 4. This information may be ordered from ASIS/NAPS, Microfiche Publications, P. O. Box 3515, Grand Central Station, New York 10017. Remit in advance $\$ 3.00$ for microfiche copy, or for photocopy, $\$ 5.00$ up to 20 pages plus $25 \notin$ for additional pages. Checks should be made payable to Microfiche Publications. that one family was eliminated from consideration and that a few borderline individuals changed classification made it necessary to examine the various possible mechanisms of monogenic inheritance of low IDBH values. Both parents in 15 families $(71 \%)$ had IDBH levels of greater than $100 \mathrm{ng} / \mathrm{ml}$, in 5 families one parent had very low IDBH, and in 1 family both parents had very low IDBH concentrations. Since IDBH and enzymatic DBH values correlated so well in the members of these families, it was expected that IDBH would show an apparent pattern of inheritance similar to that of enzymatic plasma $\mathrm{DBH}$, and this proved to be the case. If very low IDBH is inherited as a single gene of large effect, the relative lack of vertical transmission in the pedigrees makes dominant inheritance less
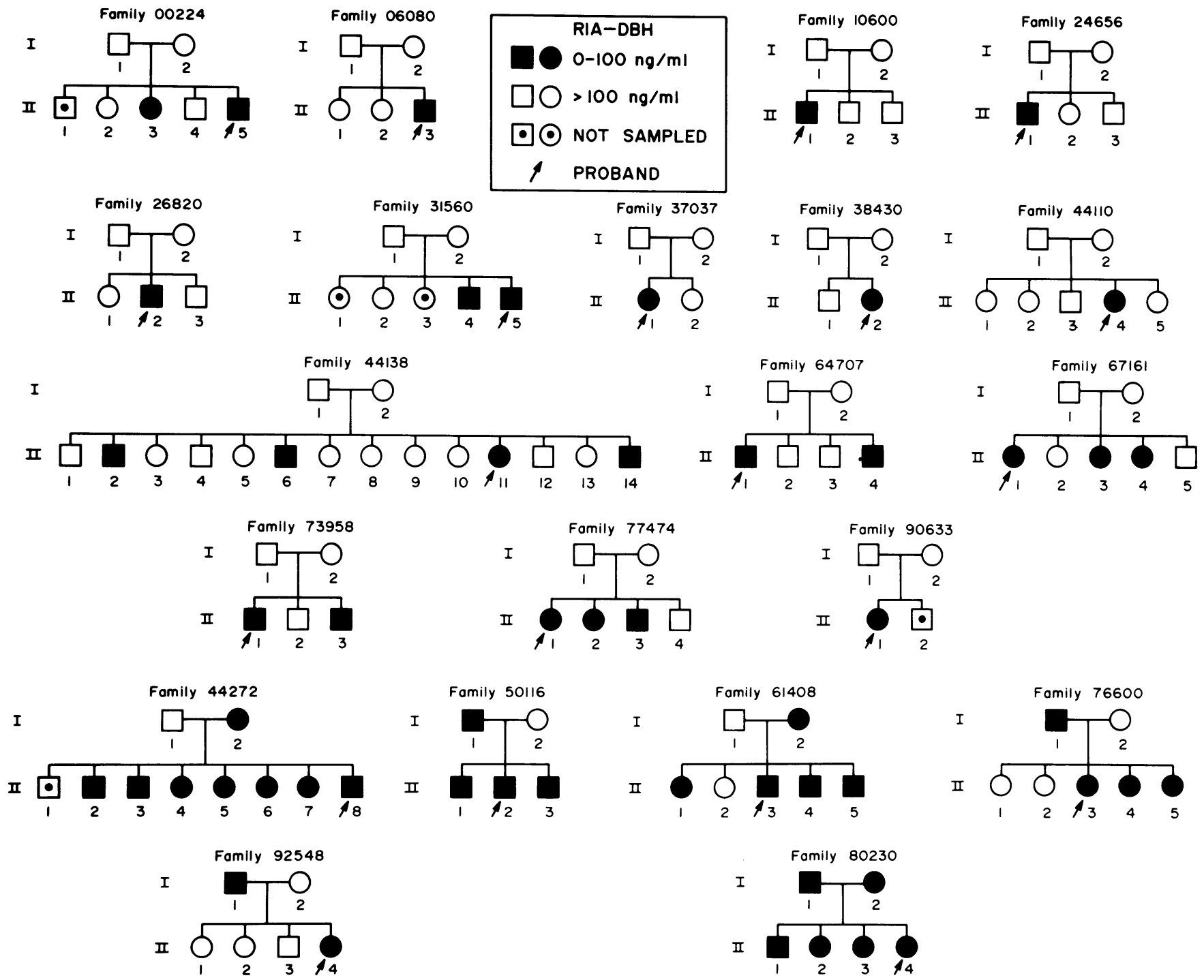

FIGURE 4 Pedigrees of 21 families in which at least one child had very low plasma IDBH $(<100 \mathrm{ng} / \mathrm{ml})$. 
likely as a mechanism. Boys and girls are approximately equally represented among the children with very low IDBH ( 25 boys, 23 girls), and there are 11 girls with very low IDBH among the children of parents who both have IDBH levels greater than $100 \mathrm{ng} / \mathrm{ml}$. These facts make sex-linked inheritance very unlikely. The possibility of autosomal recessive inheritance of very low IDBH was tested by several different methods of segregation analysis (Table I). Only data from families in which both parents had IDBH values of more than $100 \mathrm{ng} / \mathrm{ml}$ were used in these calculations. Each of the methods for testing the recessive hypothesis, the "direct a priori method" (27), "single ascertainment" (27), and the "Weinberg proband method" (28), involves slightly different assumptions, but in each case the calculated segregation parameter was compatible with the autosomal recessive inheritance of an allele for very low IDBH - an allele that segregates with the allele for very low plasma enzymatic DBH activity.

IDBH in blood of heterozygotes. These results are compatible with the hypothesis that the presence of the allele for very low plasma enzymatic DBH activity, $d$, results in a decrease in plasma IDBH that is in direct proportion to the decrease in enzymatic activity. Although heterozygotes for this allele $(D d)$ cannot be reliably separated from $D D$ subjects in a randomly selected population, they can be identified by family studies. Since the data are compatible with the autosomal recessive inheritance of low IDBH, presumably by virtue of the presence of the allele $d$, it is possible to define heterozygotes on the basis of IDBH levels. Parents of homozygous recessive subjects (IDBH $<100$ $\mathrm{ng} / \mathrm{ml}$ ) who themselves have IDBH values of greater than $100 \mathrm{ng} / \mathrm{ml}$ are presumed to be heterozygous for the allele. The distribution of their IDBH values (Fig. 3, middle) has a mean value of $599 \pm 53 \mathrm{ng} / \mathrm{ml}$ (mean \pm SEM, $n=37$ ). This value is significantly different from the mean IDBH value in the 129 randomly selected subjects with IDBH of greater than $100 \mathrm{ng} / \mathrm{ml}$ $(854 \pm 37 \mathrm{ng} / \mathrm{ml}$, mean \pm SEM, $P<0.005)$. The mean value in blood of these heterozygotes is also sig-

TABLE I

Human Plasma IDBH: Testing the Recessive Hypothesis

\begin{tabular}{lcc}
\hline \multicolumn{1}{c}{ Method } & $\begin{array}{c}\text { Calculated segregation } \\
\text { parameter }\end{array}$ & $\begin{array}{c}\text { Expected } \\
\text { value }\end{array}$ \\
\hline Direct a priori method & 0.292 & 0.25 \\
Single ascertainment & $0.25 \pm 0.065^{*}$ & 0.25 \\
Weinberg proband method & $0.274 \pm 0.079^{*}$ & 0.25 \\
\hline
\end{tabular}

The results of various methods of correction for the bias of ascertainment are shown. Only data from families in which both parents had IDBH values greater than $100 \mathrm{ng} / \mathrm{ml}$ were used in the calculations.

* SEM. nificantly different from that of the entire population of randomly selected subjects $(824 \pm 38 \mathrm{ng} / \mathrm{ml}, n=134$, $P<0.005)$. Therefore, heterozygotes have values of IDBH that are intermediate between those found in homozygous recessive individuals and values present in blood from a randomly selected population.

$I D B H$ in siblings of probands. The distribution of IDBH values from siblings of probands in families in which both parents had IDBH values of greater than $100 \mathrm{ng} / \mathrm{ml}$ is also shown in Fig. 3. Of these siblings, $25 \%$ had very low IDBH, and the distribution suggests the existence of another group with a mean IDBH value close to that of heterozygotes.

Family with abnormal homospecific activity. As was noted above, one proband for very low enzymatic DBH had values of IDBH that were repeatedly found to be above $100 \mathrm{ng} / \mathrm{ml}$. The ratio of IDBH:DBH enzymatic activity was increased in this proband. When such an IDBH:DBH ratio was calculated for the blood samples from randomly selected subjects with values greater than $100 \mathrm{ng} / \mathrm{ml}(n=129)$, the average ratio was $1.10 \pm 0.351$ (mean $\pm S D$ ). The mean ratio for the subjects from the family studies with values greater than $100 \mathrm{ng} / \mathrm{ml}$ was $1.39 \pm 0.53$ (mean $\pm \mathrm{SD}, n=79)$. However, when members of the family of the proband with the apparent increase in the ratio of IDBH to enzymatic DBH were tested, three of the subjects, the proband's mother and two brothers, had ratios of $2.67,4.33$, and 2.79 , respectively. These were the highest ratios found in any of the 208 subjects tested. These data suggest the existence of a rare allele that results in a decrease in DBH enzymatic activity without the expected proportionate decrease in IDBH. Further studies will be necessary to test this hypothesis.

Enzymatic activity in subjects with very low $D B H$. The level of plasma DBH enzymatic activity in individuals with very low DBH activity is not measured accurately by the standard enzyme assay which uses phenylethylamine as substrate. It can only be determined with certainty that such samples contain less than $50 \mathrm{U} / \mathrm{ml}$ of activity. It was important to determine whether the blood from these subjects contained measurable plasma DBH enzymatic activity. Therefore, DBH enzymatic activity was measured with tyramine as a substrate instead of phenylethylamine in samples that were diluted less than those used in the routine assay procedure. For selected samples with a range of enzymatic activity from 50 to $2000 \mathrm{U}$, the correlation between results obtained with the "tyramine assay" and the "phenylethylamine assay" was excellent $(r=0.94$, $n=20, P<0.001$, Fig. 5). Plasma samples from 59 homozygotes for the allele for very low enzymatic DBH were assayed with tyramine as a substrate, and the results are shown in Fig. 6. The values ranged from 2.7 to $100.3 \mathrm{nmol}$ of octopamine produced per hour per milliliter of plasma, with a mean of 26.8 and a me- 


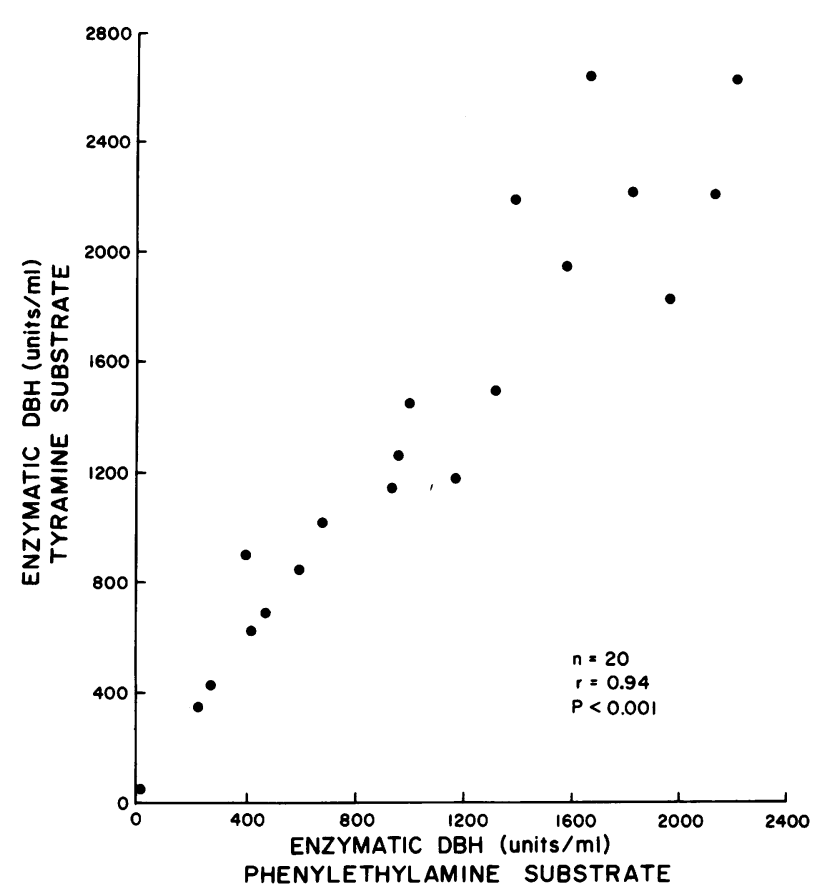

FIGURE 5 Correlation of human plasma DBH enzymatic activity using two different substrates. $\mathrm{DBH}$ activity in plasma from 20 individuals was measured both with phenylethylamine as substrate and with tyramine as substrate.

dian of 18.4. These values are similar to those found in the blood of adult rats with an assay which uses tyramine as a substrate (29). Values in blood of other quadripeds have DBH activity very similar to that of the rat. $^{3}$ DBH activity for subjects with very low enzyme activity are within a range that indicates the presence of true enzymatic DBH activity.

IDBH was measured in five of these samples by radioimmunoassay with increased quantities of plasma. In each case an easily measurable level of IDBH was found, and each dilution binding curve was superimposable on the standard curve of the purified pheochromocytoma DBH. Therefore, homozygotes for the allele for low DBH or low IDBH had very low but measurable levels of both enzymatic activity and immunoreactive protein.

\section{DISCUSSION}

This study confirms earlier reports of a significant correlation of IDBH values with enzymatic DBH activity in human plasma (13-16). In addition, it has been demonstrated that the distribution of IDBH levels in blood from a randomly selected population includes a subgroup with very low levels of immunoreactive DBH protein. There was a high degree of correlation of IDBH levels measured with three different antibody

${ }^{3}$ Weinshilboum, R. Unpublished observation. preparations, and a significant sibling-sibling correlation of IDBH values was demonstrated. The results of studies of families of probands for low enzymatic DBH activity were compatible with the autosomal recessive inheritance of very low IDBH, and the allele segregated with the allele for very low plasma enzymatic DBH. There were detectable levels of both enzymatic DBH and IDBH in blood of homozygotes for this allele. These results are compatible with the conclusion that the presence of the allele for very low enzymatic DBH results in a decrease in the total quantity of $\mathrm{DBH}$ protein in human blood.

Several possible mechanisms have been suggested by which genetic factors might influence human plasma DBH activity (12). These include differences in DBH structure, differences in the quantity of DBH in neural and adrenal tissue, differences in vesicle binding of $\mathrm{DBH}$, differences in the rate of release of $\mathrm{DBH}$, differences in the access of DBH to the circulation, and differences in the rate of clearance of the enzyme from the blood. Although the results of this study do not clearly establish the biochemical basis of genetically mediated differences in plasma $\mathrm{DBH}$ activity, they do begin to limit the possible explanations. In addition to the common polymorphism represented by the allele $d$ (gene frequency $\sim 0.2, \sim 32 \%$ of the population heterozygous), it is likely that other genetic factors may affect DBH levels. For example, preliminary evidence has been presented here that in one family the homospecific DBH activity is different than that found in the rest of the population. If this variant proves to be genetic, it could involve either the same locus as the allele pair $D$ and $d$ or an additional locus (or loci).

It is important that several antibody preparations be tested in any study in which antibodies are used to measure protein concentrations. In this study, relative IDBH values as measured with three different antibodies showed a high degree of correlation. Other in-

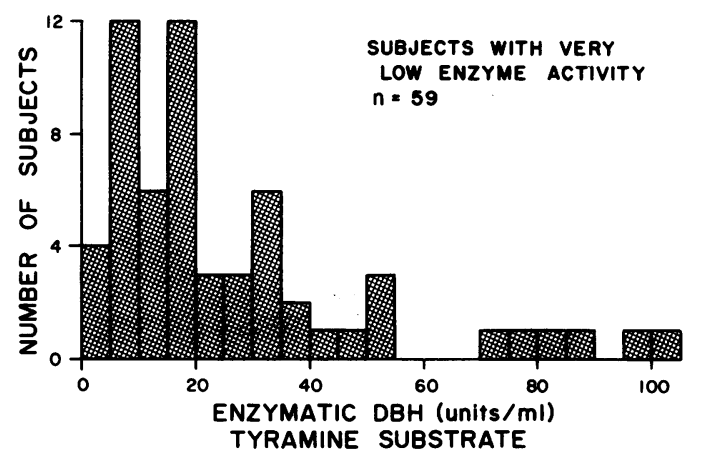

FIGURE 6 Frequency distribution of plasma DBH enzymatic activity in $\mathbf{5 9}$ homozygotes for the allele for very low plasma DBH. Tyramine was used as substrate for these determinations. 
vestigators have found higher apparent immunoreactive levels than are reported here $(14,16)$. The reason for these differences is not clear. Included among the possible explanations are differences in protein measurement, differences in antibody reactivity, or differences in labeled antigen reactivity.

It has been suggested that plasma DBH activity might be a useful measure of sympathetic nervous system function in man and experimental animals $(9,10)$. Although DBH levels might prove useful as one measure of adrenergic function in serial determinations in a given individual, it is obvious that our understanding of the relative importance of many factors, especially genetic factors, that affect plasma $\mathrm{DBH}$ will have to be improved before we will be able to properly interpret measurements of this plasma enzyme activity or IDBH levels in clinical studies.

\section{ACKNOWLEDGMENTS}

We thank Luanne Wussow and Fredrick Raymond for their assistance with these studies.

This work was supported in part by National Institutes of Health grants NS 11014 and HL 17487-1, and by Minnesota Heart Association grant-in-aid no. 23.

\section{REFERENCES}

1. Kaufman, S., and S. Friedman. 1965. Dopamine-betahydroxylase. Pharmacol. Rev. 17: 71-100.

2. Oka, K., K. Kajikawa, T. Ohuchi, H. Yoshida, and R. Imaizumi. 1967. Distribution of dopamine- $\beta$-hydroxylase in subcellular fractions of adrenal medulla. Life Sci. 6: 461-465.

3. Stjärne, L., and F. Lishajko. 1967. Localization of different steps in noradrenaline synthesis to different fractions of a bovine splenic nerve homogenate. Biochem. Pharmacol. 16: 1719-1728.

4. de Potter, W. P., A. F. de Schaepdryver, E. J. Moerman, and A. D. Smith. 1969. Evidence for the release of vesicle proteins together with noradrenaline upon stimulation of the splenic nerve. J. Physiol. (Lond.). 204: 102P-104P.

5. Geffen, L. B., B. G. Livett, and R. A. Rush. 1969. Immunological localization of chromogranins in sheep sympathetic neurons, and their release by nerve impulses. J. Physiol. (Lond.). 204: 58P-59P.

6. Viveros, O. H., L. Arqueros, and N. Kirshner. 1968. Release of catecholamines and dopamine- $\beta$-oxidase from the adrenal medulla. Life Sci. Part I. Physiol. Pharmacol. 7: 609-618.

7. Smith, A. D., W. D. de Potter, E. J. Moerman, and A. F. de Schaepdryver. 1970. Release of dopamine- $\beta$-hydroxylase and chromogranin $A$ upon stimulation of the splenic nerve. Tissue Cell. 2: 547-568.

8. Weinshilboum, R. M., N. B. Thoa, D. G. Johnson, I. J. Kopin, and J. Axelrod. 1971. Proportional release of norepinephrine and dopamine- $\beta$-hydroxylase from sympathetic nerves. Science (Wash. D. C.). 174: 13491351.

9. Weinshilboum, R., and J. Axelrod. 1971. Serum dopamine$\beta$-hydroxylase. Circ. Res. 28: 307-315.

10. Rush, R. A., and L. B. Geffen. 1972. Radioimmunoassay and clearance of circulating dopamine- $\beta$-hydroxylase. Circ. Res. 31: 444-452.
11. Weinshilboum, R. M., F. A. Raymond, L. R. Elveback, and W. H. Weidman. 1973. Serum dopamine- $\beta$-hydroxylase activity: sibling-sibling correlation. Science (Wash. D. C.). 181: $943-945$.

12. Weinshilboum, R. M., H. G. Schrott, F. A. Raymond, W. H. Weidman, and L. R. Elveback. 1975. Inheritance of very low serum dopamine- $\beta$-hydroxylase. Am. J. Hum. Genet. 27: $573-585$.

13. Dunnette, J., and R. Weinshilboum. 1976. Human serum dopamine- $\beta$-hydroxylase: correlation of enzymatic activity with immunoreactive protein in genetically defined samples. Am. J. Hum. Genet. 28: 155-166.

14. Ebstein, R. P., D. H. Park, L. S. Freedman, S. M. Levitz, T. Ohuchi, and M. Goldstein. 1973. A radioimmunoassay of human circulatory dopamine- $\beta$-hydroxylase. Life Sci. 13: $769-774$.

15. Ciaranello, R. D., and G. F. Wooten. 1974. Proportionality between dopamine- $\beta$-hydroxylase and enzyme protein concentration in human serum. Pharmacology (Basel). 12: $272-282$.

16. Rush, R. A., P. E. Thomas, and S. Udenfriend. 1975. Measurement of human dopamine- $\beta$-hydroxylase in serum by homologous radioimmunoassay. Proc. Natl. Acad. Sci. U. S. A. 72: 750-752.

17. Molinoff, P. B., R. Weinshilboum, and J. Axelrod. 1971. A sensitive enzymatic assay for dopamine- $\beta$-hydroxylase. J. Pharmacol. Exp. Ther. 178: 425-431.

18. Böhlen, P., S. Stein, W. Dairman, and S. Udenfriend. 1973. Fluorometric assay of proteins in the nanogram range. Arch. Biochem. Biophys. 155: 213-220.

19. Smith, A. D., and H. Winkler. 1967. A simple method for the isolation of adrenal chromaffin granules on a large scale. Biochem. J. 103: 480-482.

20. Rush, R. A., P. E. Thomas, S. H. Kindler, and S. Udenfriend. 1974. The interaction of dopamine- $\beta$-hydroxylase with concanavalin $A$ and its use in enzyme purification. Biochem. Biophys. Res. Commun. 57: 1301-1305.

21. Miras-Portugal, M. T., D. Aunis, and P. Mandel. 1975. Human serum dopamine- $\beta$-hydroxylase: purification, molecular weight, presence of sugars and kinetic properties. Biochimie (Paris). 57: 669-675.

22. Bolton, A. E., and W. M. Hunter. 1973. The labelling of proteins to high specific radioactivities by conjugation to a ${ }^{125}$ I-containing acylating agent. Biochem. J. 133: 529-539.

23. Gleich, G. J., A. K. Averbeck, and H. A. Swedlund. 1971. Measurement of IgE in normal and allergic serum by radioimmunoassay. J. Lab. Clin. Med. 77: 690-698.

24. Greenwood, F. C., W. M. Hunter, and J. S. Glover. 1963. The preparation of ${ }^{131}$ I-labelled human growth hormone of high specific radioactivity. Biochem. J. 89: 114-123.

25. Rabinowitz, D., J. Bell, R. Benveniste, and S. Schwartz. 1973. Multiple antigenic and biological determinants of human FSH and its subunits. Nat. New Biol. 245: 245-247.

26. Arnaud, C. D. 1973. Immunochemical heterogeneity of circulating parathyroid hormone in man: sequel to an original observation by Berson and Yalow. Mt. Sinaı J. Med. 40: 422-432.

27. Li, C. C. 1961. Human Genetics. McGraw-Hill Book Company, New York. 58-78.

28. Cavalli-Storza, L. L., and W. F. Bodmer. 1971. The Genetics of Human Populations. W. H. Freeman and Company, San Francisco. 856.

29. Olukotun, A., J. Dunnette, and R. Weinshilboum. 1977. Dissociation of changes in enzymatic and immunoreactive rat serum dopamine- $\beta$-hydroxylase during growth and development. J. Pharmacol. Exp. Ther. 201: 375-385. 